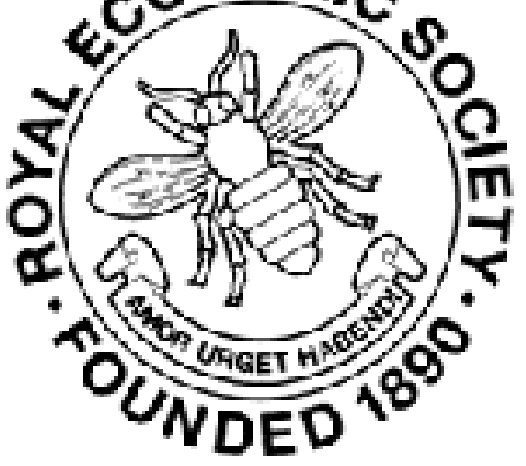

Mr. and Mrs. Webb on Consumers' Co-Operation

Author(s): A. C. Pigou

Source: The Economic Journal, Vol. 32, No. 125 (Mar., 1922), pp. 53-57

Published by: Wiley on behalf of the Royal Economic Society

Stable URL: http://www.jstor.org/stable/2223109

Accessed: 27-06-2016 03:36 UTC

Your use of the JSTOR archive indicates your acceptance of the Terms \& Conditions of Use, available at

http://about.jstor.org/terms

JSTOR is a not-for-profit service that helps scholars, researchers, and students discover, use, and build upon a wide range of content in a trusted digital archive. We use information technology and tools to increase productivity and facilitate new forms of scholarship. For more information about JSTOR, please contact support@jstor.org.

Royal Economic Society, Wiley are collaborating with JSTOR to digitize, preserve and extend access to The Economic Journal 


\section{MR. AND MRS. WEBB ON CONSUMERS' CO-OPERATION 1}

Is The Consumers' Co-operative Movement Mr. and Mrs. Webb have added yet another important work to their wonderful series of social studies. There is the same clear arrangement, the same power of lucid narrative, the same mastery of detail and boldness of generalisation that distinguish Industrial Democracy and its numerous companion volumes. It is not necessary to agree with the authors' conclusions or analyses-and, indeed, there is much with which the present writer does not agree-in order to recognise the high service that they have rendered, and are still rendering, to social science. Economists of a different school, or, more properly, a different method of economic thought, will not be the last to offer their tribute of respectful congratulation.

The Consumers' Co-operative Movement is divided into six chapters, entitled respectively, The Co-operative Store, Federal Institutions, The Co-operative Employees, The Effect upon the Co-operative Movement of the Great War, Some Remediable Defects and Shortcomings in the Consumers' Co-operative Movement and The Future of Consumers' Co-operation. The discussion is concerned in the main with the retail stores and the two Wholesales, together with their associated productive departments and establishments in England and Scotland. Very little is said of the various purchasers' associations to be found among the farmers of Ireland and the Continent. It is recognised that, from one point of view, these might properly be regarded as instances of consumers' co-operation, but for Mr. and Mrs. Webb the essential note of the co-operative movement is the exclusion of private profit-making, and these associations, valuable as they are acknowledged to be, do not pass that test. The authors' analysis rests upon a sharp distinction between "production for use " and "production for profit." That distinction is plausible, but, as I think, in the main illusory. There is not really much to choose between a person-or group of persons-who gets bread by making it himself and one who gets it by making boots

1 The Consumers' Co-operative Movement. By Sidney and Beatrice Webb. (Longmans. 1921. Pp. 504. Price 18s.) 
for sale at a profit and buying bread with the proceeds. Each alike aims at securing the things he wants; the fact that the process of doing this has a money stage in it for one of them and not for the other is not fundamental. Nobody, of course, would suggest that the distinction has no importance. In some circumstances, particularly when monopoly is present, it is very important indeed. But Mr. and Mrs. Webb, and some others who follow them, claim for it a dominant place that not all economists would be willing to concede.

The device of the dividend on purchase has social and economic consequences that have often been described. In this work, however, especial stress is laid upon its effect on the constitution of co-operative societies. It is a potent engine for securing complete democracy of ownership and control-and a democracy, moreover, that remains always open to new-comers. Thus, since members are financially interested in their capacity as purchasers and not as shareholders, and since the amounts of their purchases vary, there is no practicable alternative to one man (or woman) one vote. On this basis all the recent developments of constitutional form that have accompanied the enormous expansion in the scale of the co-operators' work have been built up. One important characteristic in which up-to-date societies differ from earlier ones is in the greater continuity of office secured to the committee of management. In one society (the Royal Arsenal Co-operative Society) the old committee has given place to a whole-time directorate of seven persons each paid $£ 400$ a year. "This transformation of the executive, in a few of the largest societies, from a committee paid only by fees to a small number of full-time salaried officers is, perhaps, the most momentous of the changes that are now taking place in the constitution of the co-operative societies" (p. 35). The large size of many of the societies has also made necessary some modification in the method of election and of members' meetings. The device has been invented of a series of divisional gatherings, all of which are legally part of a single members' meeting, before all of which identical resolutions and amendments are placed, and the votes obtained added together to produce a decision. In rare cases there is a provision for votes to be taken by ballot without attendance at meetings. There is also to be descried by the discerning student " a first beginning, in the co-operative society, of the characteristic organ of British political democracy, the elected representative assembly, intermediate between the electorate and the executive" (p. 59). 
A very important feature of the co-operative stores in their original form was the practice of devoting a part of the accruing surplus to common purposes of a non-economic character. The educational work of the societies has been in part superseded by the universal State provision of elementary education and the widespread provision by local authorities of evening classes and free libraries. But there is still much that co-operators can do. In the big stores, "above the tiers of retail departments and showrooms there will usually be a great assembly hall for the meetings, lectures and entertainments, to which the members resort. ... There may even be smoking-rooms and billiardrooms, and certainly a lending library. . . . Not yet common, but now increasingly prevalent, is the maintenance of a country mansion for the use of the members with extensive gardens and playing-fields" (pp. 78-82). These services for the common good are not, however, made use of by more than a very small proportion of the members. There is a tendency in some societies to cut them down. There is uncertainty of aim and infirmity of purpose in educational work and a certain intellectual deadness. To the great majority of the members the societies are merely dealers in household supplies and the source of dividends on purchases. Here Mr. and Mrs. Webb regretfully record " arrested development."

The Chapter on Federal Institutions is largely concerned with the English and Scottish Wholesales, which together supply the stores with about five-eighths of all the goods they distribute. It describes their productive operations at home and abroad, and explains incidentally the comparative failure of the attempt to establish a co-operative shipping fleet. "Experience taught the directors that, whilst they could economically arrange for imports, they are not often in a position to make up full export cargoes, and the co-operative fleet has sunk down to four vessels and ten lighters" (p. 107). The constitution of the Wholesales follows closely that of the stores, but the voting power of the stores that are members varies with the amount of purchases that they make. Alongside of the Wholesale is the "Co-operative Union," which summons and manages the Co-operative Congresses. Mr. and Mrs. Webb consider it desirable that this body should become explicitly a federation of consumers' socicties only, instead of also embracing, as it now does, associations of workers organised as producers. This, of course, is an opinion which many friends of co-operation would oppose ; holding that consumers' associations should frankly ally themselves with, and lend their strength 
to help, these weak but socially valuable forms of workpeople's effort.

Chapter III on the Co-operative Employees and Chapter IV on the effect of the Great War contain much interesting material, upon which lack of space forbids comment here. In Chapter V, under the heading Remediable Defects and Shortcomings, Mr. and Mrs. Webb advance, as friendly critics, a series of practical suggestions. In the final chapter, on the future of consumers' co-operation, they touch in part on ground already covered in A Constitution for the Socialist Commonwealth of Great Britain. The keynote is struck early : " Unless we completely misinterpret the essential groundswell of British democracy, it is this consumers' co-operation, in its twofold form of voluntary associations of members (in what we now know as the Co-operative Society) and obligatory association of citizens (in Local Government)-in organic connection with an equally ubiquitous organisation of the producers by hand or by brain (in Trade Unions and Professional Associations)-which will contribute the greater part of the new social order that is destined very largely to supersede the present Capitalistic System" (pp. 383-4). It may well be that this anticipation goes too far. Mr. and Mrs. Webb scarcely attach sufficient weight to the difficulty of securing adequate capital under voluntary co-operation in forms of production that involve large risk; nor to the danger, under obligatory co-operation, of checking enterprise and experiment. Nor is the claim to greater steadiness of production under the co-operative form of industry convincing, if we allow for the fact that, were cooperation universal, there would be no fringe of private producers upon whom the variable part of the demand could be thrown. Nor, again, would " the economists themselves" readily admit parenthood of the doctrine attributed to them on p. 391, that " capitalist ownership and control inevitably mean the abstraction from the actual producers and consumers, in the form of rent, of the differential advantages of all but the worst of the instruments of production for the time being in use." But, whether or not we accept Mr. and Mrs. Webb's far-reaching forecast, there can be no doubt that voluntary and obligatory co-operation have in many fields great advantages, and are likely to play in the future an even greater part than they play now. Particular interest, therefore, attaches to the excellent discussion, beginning on $\mathrm{p}$. 396, of the relative spheres of voluntary and obligatory associations of consumers.

At the end of their long study of social machinery the authors 
emphatically declare that this machinery is made for man, not man for the machinery, and that the test of a good economic organisation is that it shall leave people time and energy, after their material needs have been satisfied, for the pursuit of higher things. "The final end to be secured by social organisation can be nothing but the largest possible amount of the highest possible development of individual personality" (p. 481). A crude and ambiguous statement this, in which it would be easy to pick holes! But the practical intention is plain, and the emphasis that Mr. and Mrs. Webb lay upon it is well-timed.

A. C. Pigou 